PENELITIAN

\title{
Validitas Skor Apache II, MSofa, dan SAPS 3 terhadap Mortalitas Pasien Non Bedah di perawatan Intensif dewasa RSUP dr Kariadi Semarang
}

Validity of Apache II Score, MSofa, and SAPS 3 against Non-Surgical Patient

\author{
Nur Hajriya Brahmi*, Danu Soesilowati*, Jati Listiyanto Pujo* \\ * Bagian Anestesiologi dan Terapi Intensif Fakultas Kedokteran Universitas Diponegoro/ RSUP Dr \\ Kariadi, Semarang
}

\begin{abstract}
Background : There are various models of systems severity of illness, used to predict mortality, effectiveness and length of stay in intensive care, predicts the number of nurses who can effectively treat patients, number of hospitalized patients, counting health costs, and one of the components of evaluation ICU performance. Required validity assessment between severity of illness models that can be applied optimally in intensive care.
\end{abstract}

Objective : To compare the validity of APACHE II, MSOFA, and SAPS3 towards mortality of medical ICU patients in dr. Kariadi Hospital Semarang

Methods : This is a diagnostic test with a retrospective cohort design. A sample of 135 samples selected by simple random sampling, which meet the inclusion and exclusion criteria. Missing value ie bilirubin assessed and considered in the interpretation of the data. Validity is obtained by performing calibration and discrimination of the research results were then compared between the results obtained. Normality using Kolmogorov test smirnoff, while homogeneity using Levenne test. Samples were calibrated by test Lameshow Hosmer goodness of fit C, and the area under the receiver operating curve. Assessment of discrimination made by a diagnostic test by creating a $2 \times 2$ table with components of patient outcome, with parsimonious methods of each scoring model

Results : ROC curve provides auROC value for APACHE II scoring, MSOFA, and SAPS 3 with the results of 0.7981, 0.7620, 0.785. From these results, the three ratings are at a good value. APACHE II is more sensitive (83.3\%) of the MSOFA (82.6\%) and SAPS 3 (79.6\%).

Conclusion : The scoring system APACHE II, SAPS 3 MSOFA and good enough to be used as a predictor of mortality, with more valid than the APACHE II and SAPS 3 MSOFA

Keywords Validity, APACHE II, MSOFA, SAPS 3

\begin{abstract}
ABSTRAK
Latar Belakang : Terdapat berbagai model sistem severity of illness, digunakan untuk
\end{abstract}


memprediksi mortalitas, keefektifitasan dan lama rawat di perawatan intensif, memprediksi jumlah perawat yang secara efektif dapat menangani pasien, banyaknya pasien yang dirawat dirumah sakit, penghitungan beban biaya kesehatan, dan salah satu komponen evaluasi performance ICU. Diperlukan penilaian validitas antara sistem severity of illness sehingga dapat diterapkan secara maksimal di perawatan intensif.

Tujuan : Membandingkan validitas sistem skoring APACHE II, MSOFA, dan SAPS3 terhadap mortalitas pasien ICU non bedah di RSUP dr. Kariadi Semarang

Metode : Penelitian ini adalah uji diagnostik dengan desain kohort retrospektif. Sampel sebanyak 135 sampel dipilih berdasarkan simple random sampling, yang memenuhi kriteria inklusi dan ekslusi. Missing value yakni bilirubin dinilai dan dipertimbangkan dalam interpretasi data. Validitas diperoleh dengan melakukan kalibrasi dan diskriminasi dari hasil penelitian kemudian dibandingkan antara hasil yang didapat.Normalitas data menggunakan uji kolmogorov smirnoff, sementara homogenitas menggunakan uji Levenne. Sampel dikalibrasi denganuji Hosmer Lameshow goodness of fit $C$, dan area under the receiver operating curve. Penilaian diskriminasi dilakukan dengan uji diagnostik dengan membuat tabel 2x2 dengan komponen pasien outcome, dengan model parsimoni dari tiap-tiap model skoring

Hasil : Kurva ROC memberikan nilai auROC untuk skoring APACHE II, MSOFA, dan SAPS 3 dengan hasil 0,7981, 0,7620, 0,785. Dari hasil tersebut, ketiga penilaian

\section{PENDAHULUAN}

Belum ada sistem skoring severity of illness yang menjadi standar baku prosedur pelayanan pada ICU RSUP Dr. Kariadi. Di Korea ${ }^{1}$, sistem skoring severity of illness untuk pasien bedah menggunakan APACHE IV dan SAPS 3 karena kedua model tersebut memberikan hasil lebih akurat sementara APACHE II terlalu berlebihan (overestimated) dalam memprediksi kematian pada populasi ini. Penelitian yang dilakukan Antonelli et $a l^{2}$ melingkupi 40 ICU di 16 negara pada pasien trauma, memberikan hasil bahwa SOFA sangat reliable mendeteksi disfungsi organ dan penggunaannya secara berkala mampu mengindentifikasi pasien perawatan lama (prolonged ICU stay) dan akurasi prediksi kematiannya. Suatu studi di Prancis dilakukan oleh Lemonier et $a l^{3}$ mengenai penggunaan APACHE II dan SAPS 2 pada pasien medis memberi hasil bias yang besar dari pengamat yang berbeda sehingga kurang reliable, dan menyarankan agar dilakukan perbaikan/revisi dari kedua sistem skoring ini. Penelitian yang dilakukan di ICU RSUP Sanglah, memberikan hasil Customized SOFA (CSOFA) lebih valid dibanding APACHE II untuk pasien nonbedah ${ }^{4}$, sementara penelitian di RS Hasan Sadikin memberikan hasil SOFA dan MSOFA lebih valid dalam prediksi kematian dibandingkan APACHE II pada pasien ICU bedah ${ }^{5}$. 
Berlatar belakang hal tersebut, penulis hendak membandingkan validitas terhadap prediksi mortalitas pada pasien ICU nonbedah di RSUP Dr. Kariadi menggunakan sistem skoring APACHE II, MSOFA, dan SAPS 3. Pemilihan ketiga skoring ini diantara sistem skoring lainnya adalah karena APACHE II merupakan sistem skoring yang kekerapannya lebih sering diaplikasikan pada pasien rencana rawat ICU RSUP dr. Kariadi. MSOFA merupakan modifikasi sistem SOFA yang bisa diaplikasikan dengan cepat dan mudah, dengan mensubstitusi pemeriksaan bilirubin menjadi pemeriksaan fisik ikterik. Banyak varians dari MSOFA, antara lain MSOFA inisial yakni MSOFA yang dinilai pada 24 jam pertama masuk perawatan ICU, delta MSOFA ( $\triangle$ MSOFA) yaitu selisih antara total maksimum MSOFA dengan MSOFA inisial, ataupun Maksimal SOFA (MaxSOFA) yaitu nilai tertinggi MSOFA selama perawatan di ICU. SAPS 3 merupakan sistem severity of illness scoring terkini pada ilmu terapi intensif, didasarkan dari penelitian epidemiologis terbesar didunia yang bersifat multinasional.

Metode Penelitian ini adalah uji diagnostik dengan desain kohort retrospektif. Sampel sebanyak 135 sampel dipilih berdasarkan simple random sampling, yang memenuhi kriteria inklusi dan ekslusi. Missing value yakni bilirubin dinilai dan dipertimbangkan dalam interpretasi data. Validitas diperoleh dengan melakukan kalibrasi dan diskriminasi dari hasil penelitian kemudian dibandingkan antara hasil yang didapat.Normalitas data menggunakan uji kolmogorov smirnoff, sementara homogenitas menggunakan uji Levenne. Sampel dikalibrasi denganuji Hosmer Lameshow goodness of fit $C$, dan area under the receiver operating curve. Penilaian diskriminasi dilakukan dengan uji diagnostik dengan membuat tabel 2x2 dengan komponen pasien outcome, dengan model parsimoni dari tiap-tiap model skoring

\section{Hasil Penelitian}

Penelitian ini menggunakan 135 sampel yang diikutsertakan dalam analisis data, menggunakan metode simple random sampling. Cara pemilihan sampel dilakukan secara acak menggunakan tabel angka random didasarkan pada data register pasien dari buku besar ICU selama periode 1 januari 2015 - 31 Desember 2015. Pencatatan data dilakukan di instalasi rekam medik RSUP dr Kariadi Semarang.

Hasil uji diskriminasi menggunakan kurva ROC untuk menilai sensitifitas dan spesifisitas pada skoring APACHE II. Didapatkan nilai AuROC 0,7981 dengan standard error 0,040 dan 95\% Confidence Interval = $0.719-0.877$.

Gambaran grafik AuROC (gambar 5.1) memperlihatkan sensitifitas dan spesifisitas terbaik dari skoring APACHE II ada pada nilai $\geq 1$ 14 memberi nilai overall 70,37 \%, yang berarti pada nilai di atas 14 skoring ini 
akan semakin akurat dalam memprediksi mortalitas. Peningkatan skor pada APACHE II akan meningkatkan pula peluang terjadinya mortalitas.

Hasil uji diskriminasi menggunakan kurva ROC untuk menilai sensitifitas dan spesifisitas pada skoring MSOFA pada 24 jam pertama masuk perawatan ICU. Didapatkan nilai AuROC 0,7620 dengan standard error 0,040 dan 95\% Confidence Interval $=0.684-0.841$.

Gambaran grafik AuROC (gambar 5.2) memperlihatkan sensitifitas dan spesifisitas terbaik dari skoring MSOFA 24 jam ada pada nilai $\geq 4$ memberi nilai overall $68,15 \%$, yang berarti pada nilai di atas 4 skoring ini akan semakin akurat dalam memprediksi kegagalan organ yang pada akhirnya akan menyebabkan mortalitas. Namun MSOFA merupakan penilaian continue yang dilakukan perhari, sehingga bila diawal telah kita ketahui prognosis kegagalan organ yang mungkin terjadi, diharapkan perawatan intensif untuk pasien akan lebih komprehensif sehingga kerusakan organ yang sedang berjalan dapat diminimalkan hingga tidak terjadi kerusakan lebih lanjut, berhubungan dengan kesembuhan organ.

Pada penilaian prediksi mortalitas skoring SAPS 3, ditemukan missing value sebesar $20(14,80 \%)$ di nilai bilirubin. Oleh karena itu, digabungkanlah penilaian ikterik dengan nilai bilirubin, sehingga total sampel tetap 135, dimana bila pasien tidak ikterik maka nilai bilirubin dianggap normal (nilai 1), namun bila pasien ikterik dan tidak ada nilai bilirubinnya, maka dianggap nilai bilirubin abnormal (nilai 2). Rentang nilai normal pemeriksaan bilirubin di RSUP dr Kariadi adalah $<1,2 \mathrm{mg} / \mathrm{dl}$. Pada semua sampling yang tidak memiliki nilai bilirubin, tidak ditemukan ikterik, sehingga diberikan nilai 1.

Dari hasil analisa diskriminasi dengan menggunakan kurva ROC untuk menilai sensitifitas dan spesifisitas skoring SAPS 3 didapatkan nilai AuROC 0,785 dengan standard error 0,039 dan $95 \%$ Confidence Interval $=0.707-0.862$.

Gambaran grafik AuROC (gambar 5.5) memperlihatkan sensitifitas dan spesifisitas terbaik dari skoring SAPS 3 ada pada nilai $\geq 58$ memberi nilai overall $70,37 \%$, yang berarti pada nilai di atas 58 skoring ini akan semakin akurat dalam memprediksi mortalitas, dimana peningkatan skor akan meningkatkan pula peluang terjadinya mortalitas.

\section{PEMBAHASAN}

Pada karakteristik pasien pada penelitian ini menunjukkan adanya perbedaan bermakna antara jenis kelamin laki-laki dengan perempuan $\mathrm{p}$ $=0,011(\mathrm{p}<0,05)$, dimana jenis kelamin mempengaruhi mortalitas dari pada pasien non bedah yang dirawat di ICU RSUP dr Kariadi. Hal ini disebabkan bila dilihat dari tabel alasan 
masuk ICU, maka pasien gangguan kardiovaskular merupakan penyebab terbanyak perawatan ICU. Pada penelitian yang dilakukan Sedlon $\mathrm{P}^{6}$, jenis kelamin mempengaruhi mortalitas pasien, dipengaruhi oleh faktor riwayat dilakukannya resusitasi sebelum masuk perawatan intensif, dan kebutuhan atas ventilasi mekanik. Qiao ${ }^{7}$ juga mendapatkan bahwa jenis kelamin mempengaruhi mortalitas pada penelitiannya mengenai outcome pasien ICU geriartri di cina didasarkan APACHE II dan SOFA, namun tidak dijelaskan lebih lanjut di penelitian tersebut.

Dari variabel umur, ditemukan data tidak terdistribusi normal. Rerata \pm SD umur kelompok meninggal adalah $52.96 \pm 16.65$, dengan minimal usia kelompok meninggal adalah 18 dan maksimal usia kelompok meninggal 91 tahun. Pada kelompok hidup, rerata \pm $\mathrm{SD}$ adalah 53.01 \pm 13.51, dengan minimal usia kelompok hidup 23 tahun dan maksimal 79 tahun. Namun pada hubungan kemaknaan : tidak bermakna dengan $p$ value $0,986(p>0,05)$. Hal ini berbeda sekali dengan hasil penelitian yang dilakukan Qiao $^{7}$ dimana usia merupakan prediksi mortalitas independen, dimana resiko kematian meninggal dengan bertambahnya usia. Taofik $^{4}$ juga menemukan faktor usia memberikan perbedaan bermakna terhadap mortalitas dengan $\mathrm{p}$ 0,012 $(p<0,05)$. Pada kedua penelitian ini, faktor usia dikelompokkon terlebih dahulu menjadi geriatri (usia $\geq 65$ tahun), dan bukan geriatri ( usia $<65$ tahun).

Pada kejadian sepsis sebelum masuk ICU, dari 28 (100\%) kasus dengan sepsis, $22(78,6 \%)$ meninggal hanya $6(21,4 \%)$ yang hidup. Sementara pada 107 (100\%) kasus tanpa sepsis, angka survivor adalah 74 $(69,2 \%), 33(30,8 \%)$ yang meninggal. Terdapat hubungan bermakna antara kejadian sepsis sebelum masuk ICU dengan mortalitas pasien $\mathrm{p}$ value 0,001 $(p<0,05)$. Hal ini sesuai dengan hasil penelitian Kaukonen ${ }^{9}$ di Australia dan New Zealand, dimana pasien severe sepsis maupun syok sepsis meningkatkan angka mortalitas. Hal ini dikarenakan terlambatnya diagnosa sepsis pada pasien, sehingga terjadi penundaan perawatan. Hal ini diperkuat juga dengan hasil penelitian Taufiq ${ }^{4}$ di RSUP Sanglah dan Kwizera ${ }^{9}$ di Uganda, yang menunjukkan diagnosa sepsis merupakan diagnosa terbanyak mortalitas di ICU. Untuk mencegah penundaan perawatan pada pasien sepsis, pada saat ini telah disosialisasikan penerapan qSOFA $^{9}$ (quick SOFA), dimana terdapat 3 variabel yakni laju nafas (respiratory rate/RR), perubahan status mental (altered mental status), dan tekanan darah sistolik $\leq 100 \mathrm{mmHg}$, dimana nilai $\geq 2$, meningkatkan resiko kematian $\geq 10 \%$.

Pada kelompok meninggal, lama rawat di ICU rerata \pm SD $6 \pm 8,24$ hari. Sementara pada kelompok hidup rerata \pm SD $4 \pm 5,15$ hari. Hal ini mirip dengan lama rawat ICU Malaysia ${ }^{8}$ dimana lama rawat ICU disana adalah 
$4.9 \pm 7.4$ hari. Lama perawatan ICU pada penelitian ini tidak menunjukkan korelasi yang bermakna terhadap mortalitas dengan $p=0,150$. Hal ini mungkin disebabkan oleh karena turn over dari perawatan ICU yang kurang lancar dikarenakan kendala manajemen perawatan ruangan di rumah sakit pasca perawatan ICU, sehingga pasien yang telah stabil dan layak untuk keluar dari perawatan ICU masih berada di ICU, atau karena perawatan ICU di RSUP dr Kariadi bersifat paripurna untuk melakukan perawatan pasien dalam jangka panjang, Berbeda dengan penelitian yang dilakukan oleh Naved ${ }^{9}$, dimana pasien dengan skor APACHE II tinggi, memperpanjang lama rawat di ICU, dan meningkatkan angka mortalitas.

Alasan masuk ICU pada pasien non bedah di RSUP dr Kariadi pada penelitian ini adalah pada gangguan kardiovaskular. Pada kelompok meninggal, alasan masuk ICU dengan mortalitas terbanyak adalah neurologis 15(78,90\%). sementara pada kelompok hidup, kardivaskular adalah alasan masuk terbanyak yang survivor 60 $(81,1 \%)$. Ketika diuji dengan aktual mortalitas, memberikan nilai p 0,02 $(\mathrm{p}<0,05)$, namun karena variabel kategorik memiliki lebih dari 2 kategorik, nilai $\mathrm{p}$ value tidak bisa merepresentasikan kemaknaan hubungan antara tiap-tiap kategorik terhadap mortalitas aktual. Sementara di ICU Malaysia, alasan masuk terbanyak adalah berhubungan dengan trauma $(21,2 \%)$, namun sepsis adalah diagnosa terbanyak yang menyebabkan diperlukan perawatan ICU $(21,6 \%)^{8}$.

Dari hasil analisa kalibrasi dengan menggunakan kurva AuROC didapatkan untuk skoring APACHE II, MSOFA, dan SAPS 3 dengan hasil 0,7981, 0,7620, 0,785. Dari hasil tersebut, ketiga penilaian berada pada nilai baik. Nilai AuROC adalah nilai diskriminasi sistem penilaian, semakin besar nilai AuROC suatu sistem penilaian, semakin besar pula kemampuan diskriminasinya. Dari tabel 5.4, model sistem skoring APACHE II didapatkan nilai cut off $\geq 14$ dengan nilai overall $70,37 \%$, berarti pada nilai APACHE II $\geq 14$ sebaiknya perawatan dilakukan lebih intensif karena resiko mortalitas akan semakin tinggi. Pada MSOFA, didapatkan nilai cutoff $\geq 4$ dengan nilai overall $68,15 \%$, berarti diatas nilai 4 model skoring ini akan semakin akurat memprediksi kegagalan organ yang pada akhirnya berkorelasi dengan mortalitas. Penelitian ini menggunakan MSOFA inisial yakni MSOFA pada 24 jam pertama. Hal ini didasarkan pada penelitian yang dilakukan Ferreira26, SOFA inisial secara bermakna berhubungan dengan keadaan status vital. Nilai inisial SOFA hingga 9, memprediksi mortalitas hingga $33 \%$, sementara nilai inisial SOFA lebih dari 11, memprediksi mortalitas hingga 95\%. namun berkebalikan dengan penelitian yang d i 1 a k u k a $\mathrm{n}$ o 1 e $\mathrm{h}$ Vosylius et al27 menunjukkan bahwa skor SOFA berkala/periodik lebih baik pada hasil diskriminatif dibandingkan 
Tabel 1. Karakteristik sampel

\begin{tabular}{|c|c|c|c|c|c|}
\hline \multirow[t]{2}{*}{ Variabel } & \multirow[t]{2}{*}{ Kategori } & \multicolumn{2}{|c|}{ Mortalitas } & \multirow[t]{2}{*}{ Total } & \multirow[t]{2}{*}{ Kemaknaan } \\
\hline & & $\begin{array}{c}\text { Meninggal } \\
(\%) \\
\end{array}$ & $\begin{array}{c}\text { Hidup } \\
(\%) \\
\end{array}$ & & \\
\hline \multirow[t]{2}{*}{ Jenis Kelamin } & Laki-Laki & $25(31.6)$ & $54(68.4)$ & $79(100)$ & $\mathrm{p}$ value 0.011 \\
\hline & Perempuan & $30(53.6)$ & $26(46.4)$ & $56(100)$ & $\mathrm{X} 26,525$ \\
\hline \multirow[t]{4}{*}{ Umur* } & Rata-rata & 52.96 & 53.01 & 52.99 & $\mathrm{P}$ value 0.986 \\
\hline & SD & 16.65 & 13.51 & 14.81 & T-test 0,041 \\
\hline & Minimum & 18.00 & 23.00 & 18.00 & \\
\hline & Maksimum & 91.00 & 79.00 & 91.00 & \\
\hline \multirow[t]{2}{*}{ Sepsis } & $\mathrm{Ya}$ & $22(78.6)$ & $6(21.4)$ & $28(100)$ & $\mathrm{P}$ value 0.001 \\
\hline & Tidak & $33(30.8)$ & $74(69.2)$ & $107(100)$ & X2 20,942 \\
\hline \multirow[t]{5}{*}{ LOS** } & Rata-rata & 8.24 & 5.15 & 6.41 & $\mathrm{P}$ value 0.150 \\
\hline & Median & 6.00 & 4.00 & 4.00 & $Z-1,440$ \\
\hline & $\mathrm{SD}$ & 16.00 & 3.20 & 10.56 & \\
\hline & Minimum & 1.00 & 1.00 & 1.00 & \\
\hline & Maksimum & 120.00 & 19.00 & 120.00 & \\
\hline \multirow[t]{2}{*}{ Vasopressor } & $\mathrm{Ya}$ & $12(54.5)$ & $10(45.5)$ & $22(100)$ & $\mathrm{P}$ value 0.150 \\
\hline & Tidak & $43(38.1)$ & $70(61.9)$ & $113(100)$ & $\mathrm{X} 22,075$ \\
\hline Lama Rawat & Rata-rata & 5.20 & 2.43 & 3.56 & $\mathrm{P}$ value 0.001 \\
\hline sebelum masuk & Median & 2.00 & 1.00 & 1.00 & $Z-3,909$ \\
\hline \multirow[t]{3}{*}{$\mathrm{ICU}^{* *}$} & $\mathrm{SD}$ & 7.82 & 2.68 & 5.88 & \\
\hline & Minimum & 1.00 & 0.00 & 0.00 & \\
\hline & Maksimum & 43.00 & 19.00 & 43.00 & \\
\hline Alasan Masuk & Sepsis & $12(80.00)$ & $3(20.00)$ & $15(100)$ & $\mathrm{P}$ value 0.02 \\
\hline \multirow[t]{4}{*}{ ICU } & KV & $14(18.90)$ & $60(81.10)$ & $74(100)$ & X2 7,53 \\
\hline & Respiratori & $10(45.50)$ & $12(54.50)$ & $22(100)$ & \\
\hline & Neurologis & $15(78.90)$ & $4(21.10)$ & $19(100)$ & \\
\hline & Renal & $4(80.00)$ & $1(20.00)$ & $5(100)$ & \\
\hline
\end{tabular}


Tabel 2. Klasifikasi skoring APACHE II

Correctly

Cutpoint Sensitivity Specificity Classified LR+

\begin{tabular}{|c|c|c|c|c|c|}
\hline$(>=1)$ & $100.00 \%$ & $0.00 \%$ & $40.74 \%$ & & 1.0000 \\
\hline$(>=4)$ & $100.00 \%$ & $1.25 \%$ & $41.48 \%$ & 1.0127 & 0.0000 \\
\hline$(>=5)$ & $100.00 \%$ & $3.75 \%$ & $42.96 \%$ & 1.0390 & 0.0000 \\
\hline$(>=6)$ & $100.00 \%$ & $15.00 \%$ & $49.63 \%$ & 1.1765 & 0.0000 \\
\hline$(>=7)$ & $100.00 \%$ & $18.75 \%$ & $51.85 \%$ & 1.2308 & 0.0000 \\
\hline$(>=8)$ & $94.55 \%$ & $22.50 \%$ & $51.85 \%$ & 1.2199 & 0.2424 \\
\hline$(>=9)$ & $87.27 \%$ & $30.00 \%$ & $53.33 \%$ & 1.2468 & 0.4242 \\
\hline$(>=10)$ & $87.27 \%$ & $37.50 \%$ & $57.78 \%$ & 1.3964 & 0.3394 \\
\hline$(>=11)$ & $85.45 \%$ & $43.75 \%$ & $60.74 \%$ & 1.5192 & 0.3325 \\
\hline$(>=12)$ & $85.45 \%$ & $52.50 \%$ & $65.93 \%$ & 1.7990 & 0.2771 \\
\hline$(>=13)$ & $83.64 \%$ & $61.25 \%$ & $70.37 \%$ & 2.1584 & 0.2672 \\
\hline$(>=14)$ & $81.82 \%$ & $62.50 \%$ & $70.37 \%$ & 2.1818 & 0.2909 \\
\hline$(>=15)$ & $80.00 \%$ & $70.00 \%$ & $74.07 \%$ & 2.6667 & 0.2857 \\
\hline$(>=16)$ & $67.27 \%$ & $71.25 \%$ & $69.63 \%$ & 2.3399 & 0.4593 \\
\hline$(>=17)$ & $65.45 \%$ & $83.75 \%$ & $76.30 \%$ & 4.0280 & 0.4125 \\
\hline$(>=18)$ & $58.18 \%$ & $88.75 \%$ & $76.30 \%$ & 5.1717 & 0.4712 \\
\hline$(>=19)$ & $56.36 \%$ & $90.00 \%$ & $76.30 \%$ & 5.6364 & 0.4848 \\
\hline$(>=20)$ & $52.73 \%$ & $91.25 \%$ & $75.56 \%$ & 6.0260 & 0.5181 \\
\hline$(>=21)$ & $45.45 \%$ & $95.00 \%$ & $74.81 \%$ & 9.0909 & 0.5742 \\
\hline$(>=22)$ & $40.00 \%$ & $95.00 \%$ & $72.59 \%$ & 8.0000 & 0.6316 \\
\hline$(>=23)$ & $34.55 \%$ & $95.00 \%$ & $70.37 \%$ & 6.9091 & 0.6890 \\
\hline$(>=24)$ & $30.91 \%$ & $96.25 \%$ & $69.63 \%$ & 8.2424 & 0.7178 \\
\hline$(>=25)$ & $25.45 \%$ & $97.50 \%$ & $68.15 \%$ & 10.1818 & 0.7646 \\
\hline$(>=26)$ & $16.36 \%$ & $97.50 \%$ & $64.44 \%$ & 6.5455 & 0.8578 \\
\hline$(>=28)$ & $14.55 \%$ & $98.75 \%$ & $64.44 \%$ & 11.6364 & 0.8654 \\
\hline$(>=30)$ & $12.73 \%$ & $100.00 \%$ & $64.44 \%$ & & 0.8727 \\
\hline$(>=31)$ & $9.09 \%$ & $100.00 \%$ & $62.96 \%$ & & 0.9091 \\
\hline$(>=32)$ & $7.27 \%$ & $100.00 \%$ & $62.22 \%$ & & 0.9273 \\
\hline$(>=35)$ & $3.64 \%$ & $100.00 \%$ & $60.74 \%$ & & 0.9636 \\
\hline$(x=40)$ & $1.82 \%$ & $100.00 \%$ & $60.00 \%$ & & 0.9818 \\
\hline
\end{tabular}


Tabel 3. Klasifikasi skoring MSOFA

\begin{tabular}{lccccc}
\hline & & \multicolumn{3}{c}{ Correctly } \\
Cutpoint & Sensitivity & Specificity & Classified & LR+ & LR- \\
\hline & & & & \\
\hline & & & & \\
$(>=0)$ & $100.00 \%$ & $0.00 \%$ & $40.74 \%$ & 1.0000 \\
$(>=1)$ & $100.00 \%$ & $20.00 \%$ & $52.59 \%$ & 1.2500 & 0.0000 \\
$(>=2)$ & $94.55 \%$ & $36.25 \%$ & $60.00 \%$ & 1.4831 & 0.1505 \\
$(>=3)$ & $87.27 \%$ & $48.75 \%$ & $64.44 \%$ & 1.7029 & 0.2611 \\
$(>=4)$ & $67.27 \%$ & $68.75 \%$ & $68.15 \%$ & 2.1527 & 0.4760 \\
$(>=5)$ & $56.36 \%$ & $78.75 \%$ & $69.63 \%$ & 2.6524 & 0.5541 \\
$(>=6)$ & $47.27 \%$ & $85.00 \%$ & $69.63 \%$ & 3.1515 & 0.6203 \\
$(>=7)$ & $34.55 \%$ & $87.50 \%$ & $65.93 \%$ & 2.7636 & 0.7481 \\
$(>=8)$ & $25.45 \%$ & $95.00 \%$ & $66.67 \%$ & 5.0909 & 0.7847 \\
$(>=9)$ & $16.36 \%$ & $98.75 \%$ & $65.19 \%$ & 13.0909 & 0.8470 \\
$(>=10)$ & $12.73 \%$ & $98.75 \%$ & $63.70 \%$ & 10.1818 & 0.8838 \\
$(>=13)$ & $3.64 \%$ & $100.00 \%$ & $60.74 \%$ & & 0.9636
\end{tabular}


Tabel 4. Klasifikasi skoring SAPS3

\section{Correctly}

Cutpoint Sensitivity Specificity Classified LR + LR-

\begin{tabular}{|c|c|c|c|c|c|}
\hline$(>=30)$ & $100.00 \%$ & $0.00 \%$ & $40.74 \%$ & & 1.0000 \\
\hline$(>=33)$ & $100.00 \%$ & $1.25 \%$ & $41.48 \%$ & 1.0127 & 0.0000 \\
\hline$(>=36)$ & $100.00 \%$ & $2.50 \%$ & $42.22 \%$ & 1.0256 & 0.0000 \\
\hline$(>=37)$ & $98.18 \%$ & $7.50 \%$ & $44.44 \%$ & 1.0614 & 0.2424 \\
\hline$(>=38)$ & $98.18 \%$ & $8.75 \%$ & $45.19 \%$ & 1.0760 & 0.2078 \\
\hline$(>=39)$ & $98.18 \%$ & $16.25 \%$ & $49.63 \%$ & 1.1723 & 0.1119 \\
\hline$(>=40)$ & $96.36 \%$ & $17.50 \%$ & $49.63 \%$ & 1.1680 & 0.2078 \\
\hline$(>=41)$ & $96.36 \%$ & $21.25 \%$ & $51.85 \%$ & 1.2237 & 0.1711 \\
\hline$(>=42)$ & $96.36 \%$ & $22.50 \%$ & $52.59 \%$ & 1.2434 & 0.1616 \\
\hline$(>=43)$ & $96.36 \%$ & $30.00 \%$ & $57.04 \%$ & 1.3766 & 0.1212 \\
\hline$(>=44)$ & $96.36 \%$ & $36.25 \%$ & $60.74 \%$ & 1.5116 & 0.1003 \\
\hline$(>=45)$ & $96.36 \%$ & $42.50 \%$ & $64.44 \%$ & 1.6759 & 0.0856 \\
\hline$(>=46)$ & $96.36 \%$ & $43.75 \%$ & $65.19 \%$ & 1.7131 & 0.0831 \\
\hline$(>=47)$ & $96.36 \%$ & $47.50 \%$ & $67.41 \%$ & 1.8355 & 0.0766 \\
\hline$(>=48)$ & $94.55 \%$ & $51.25 \%$ & $68.89 \%$ & 1.9394 & 0.1064 \\
\hline$(>=49)$ & $92.73 \%$ & $53.75 \%$ & $69.63 \%$ & 2.0049 & 0.1353 \\
\hline$(>=50)$ & $90.91 \%$ & $57.50 \%$ & $71.11 \%$ & 2.1390 & 0.1581 \\
\hline$(>=51)$ & $85.45 \%$ & $61.25 \%$ & $71.11 \%$ & 2.2053 & 0.2375 \\
\hline$(>=52)$ & $80.00 \%$ & $62.50 \%$ & $69.63 \%$ & 2.1333 & 0.3200 \\
\hline$(>=53)$ & $76.36 \%$ & $66.25 \%$ & $70.37 \%$ & 2.2626 & 0.3568 \\
\hline$(>=54)$ & $67.27 \%$ & $73.75 \%$ & $71.11 \%$ & 2.5628 & 0.4438 \\
\hline$(>=55)$ & $65.45 \%$ & $75.00 \%$ & $71.11 \%$ & 2.6182 & 0.4606 \\
\hline$(>=57)$ & $61.82 \%$ & $75.00 \%$ & $69.63 \%$ & 2.4727 & 0.5091 \\
\hline$(>=58)$ & $61.82 \%$ & $76.25 \%$ & $70.37 \%$ & 2.6029 & 0.5007 \\
\hline$(>=59)$ & $60.00 \%$ & $80.00 \%$ & $71.85 \%$ & 3.0000 & 0.5000 \\
\hline$(>=60)$ & $56.36 \%$ & $80.00 \%$ & $70.37 \%$ & 2.8182 & 0.5455 \\
\hline$(>=61)$ & $47.27 \%$ & $85.00 \%$ & $69.63 \%$ & 3.1515 & 0.6203 \\
\hline$(>=62)$ & $43.64 \%$ & $86.25 \%$ & $68.89 \%$ & 3.1736 & 0.6535 \\
\hline$(>=63)$ & $38.18 \%$ & $86.25 \%$ & $66.67 \%$ & 2.7769 & 0.7167 \\
\hline$(>=64)$ & $36.36 \%$ & $90.00 \%$ & $68.15 \%$ & 3.6364 & 0.7071 \\
\hline 66 ) & $7 \%$ & $0.00 \%$ & $64.44 \%$ & $\begin{array}{c}2.7273 \\
\text { Volun }\end{array}$ & $\begin{array}{c}0.8081 \\
\text { III, Nomo }\end{array}$ \\
\hline
\end{tabular}




$\begin{array}{lccccc}(>=70) & 23.64 \% & 93.75 \% & 65.19 \% & 3.7818 & 0.8145 \\ (>=71) & 23.64 \% & 96.25 \% & 66.67 \% & 6.3030 & 0.7934 \\ (>=72) & 20.00 \% & 96.25 \% & 65.19 \% & 5.3333 & 0.8312 \\ (>=73) & 18.18 \% & 96.25 \% & 64.44 \% & 4.8485 & 0.8501 \\ (>=76) & 16.36 \% & 96.25 \% & 63.70 \% & 4.3636 & 0.8689 \\ (>=82) & 10.91 \% & 97.50 \% & 62.22 \% & 4.3636 & 0.9138 \\ (>=89) & 7.27 \% & 97.50 \% & 60.74 \% & 2.9091 & 0.9510 \\ (>=94) & 5.45 \% & 97.50 \% & 60.00 \% & 2.1818 & 0.9697 \\ (>=99) & 3.64 \% & 98.75 \% & 60.00 \% & 2.9091 & 0.9758 \\ (>=114) & 1.82 \% & 100.00 \% & 60.00 \% & & 0.9818\end{array}$

Tabel 5. Model APACHE II Parsimoni

\begin{tabular}{lcrr}
\hline \multirow{2}{*}{ Prediksi Mortalitas } & \multicolumn{2}{c}{ Observasi Mortalitas } & \multirow{2}{*}{ Total } \\
\cline { 2 - 3 } & Meninggal (\%) & \multicolumn{1}{c}{ Hidup (\%) } & \\
\hline Meninggal & $40(83.3)$ & $8(16.7)$ & $48(100)$ \\
Hidup & $15(17.2)$ & $72(82.8)$ & $87(100)$ \\
\hline Total & $55(40.7)$ & $80(59.3)$ & $00)$ \\
\hline
\end{tabular}

Tabel 6. Model MSOFA Parsimoni

\begin{tabular}{lcrr}
\hline \multirow{2}{*}{ Prediksi Mortalitas } & \multicolumn{2}{c}{ Observasi Mortalitas } & \multirow{2}{*}{ Total } \\
\cline { 2 - 3 } & \multicolumn{1}{c}{ Meninggal (\%) } & \multicolumn{1}{c}{ Hidup (\%) } & \\
\hline Meninggal & $38(82.6)$ & $8(17.4)$ & $46(100)$ \\
Hidup & $17(19.1)$ & $72(80.9)$ & $89(100)$ \\
\hline Total & $55(40.7)$ & $80(59.3)$ & $00)$ \\
\hline
\end{tabular}

Tabel 7. Model SAPS 3 Parsimoni

\begin{tabular}{lcrr}
\hline Prediksi Mortalitas & \multicolumn{2}{c}{ Observasi Mortalitas } & Total \\
\cline { 2 - 3 } & \multicolumn{2}{c}{ g Meninggal (\%) } & Hidup (\%) \\
\hline Meninggal & $43(79.6)$ & $11(20.4)$ & $54(100)$ \\
Hidup & $12(14.8)$ & $69(85.2)$ & $81(100)$ \\
\hline Total & $55(40.7)$ & $80(59.3)$ & $00)$ \\
\hline
\end{tabular}




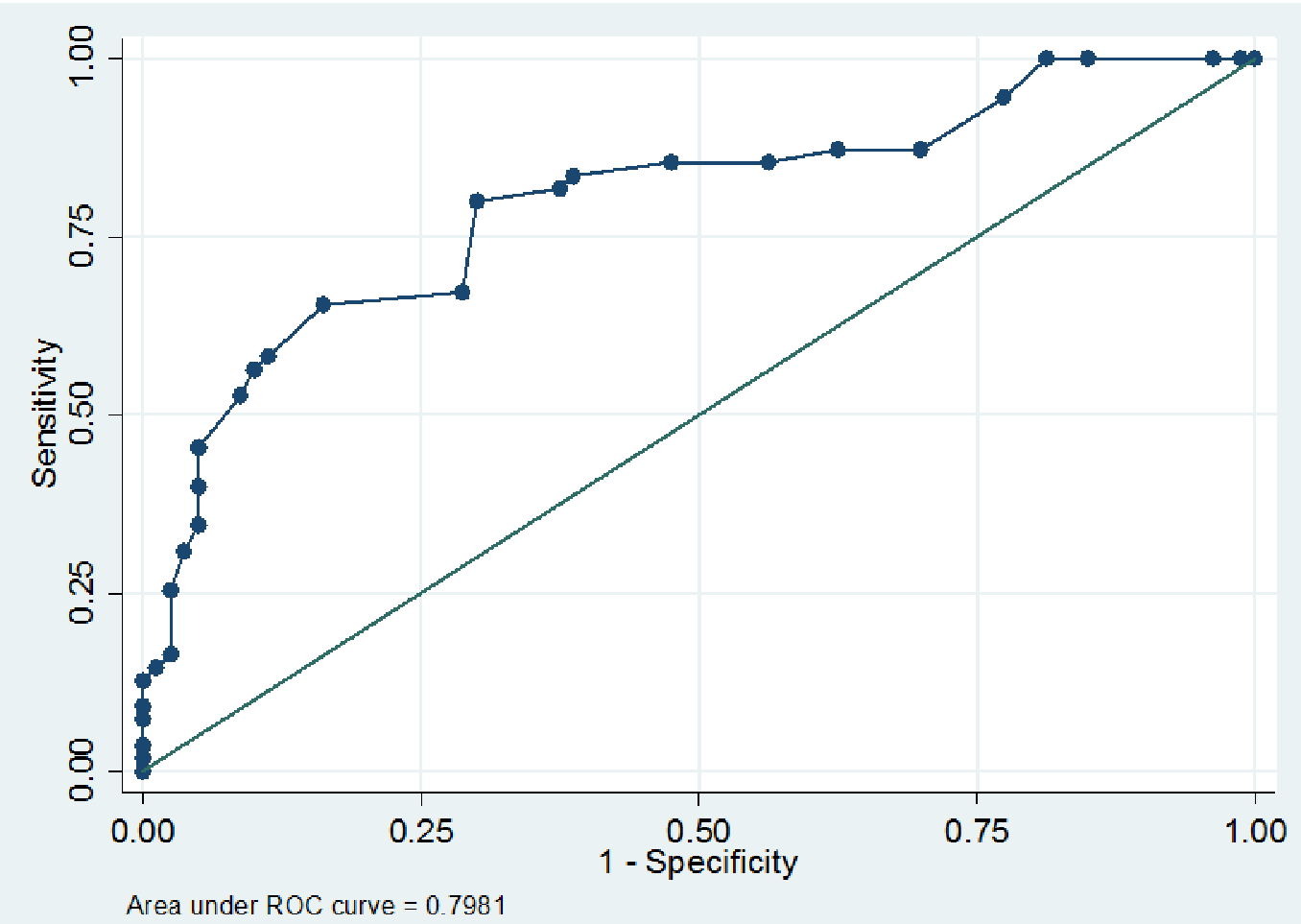

Gambar 1. Grafik AuROC APACHE II

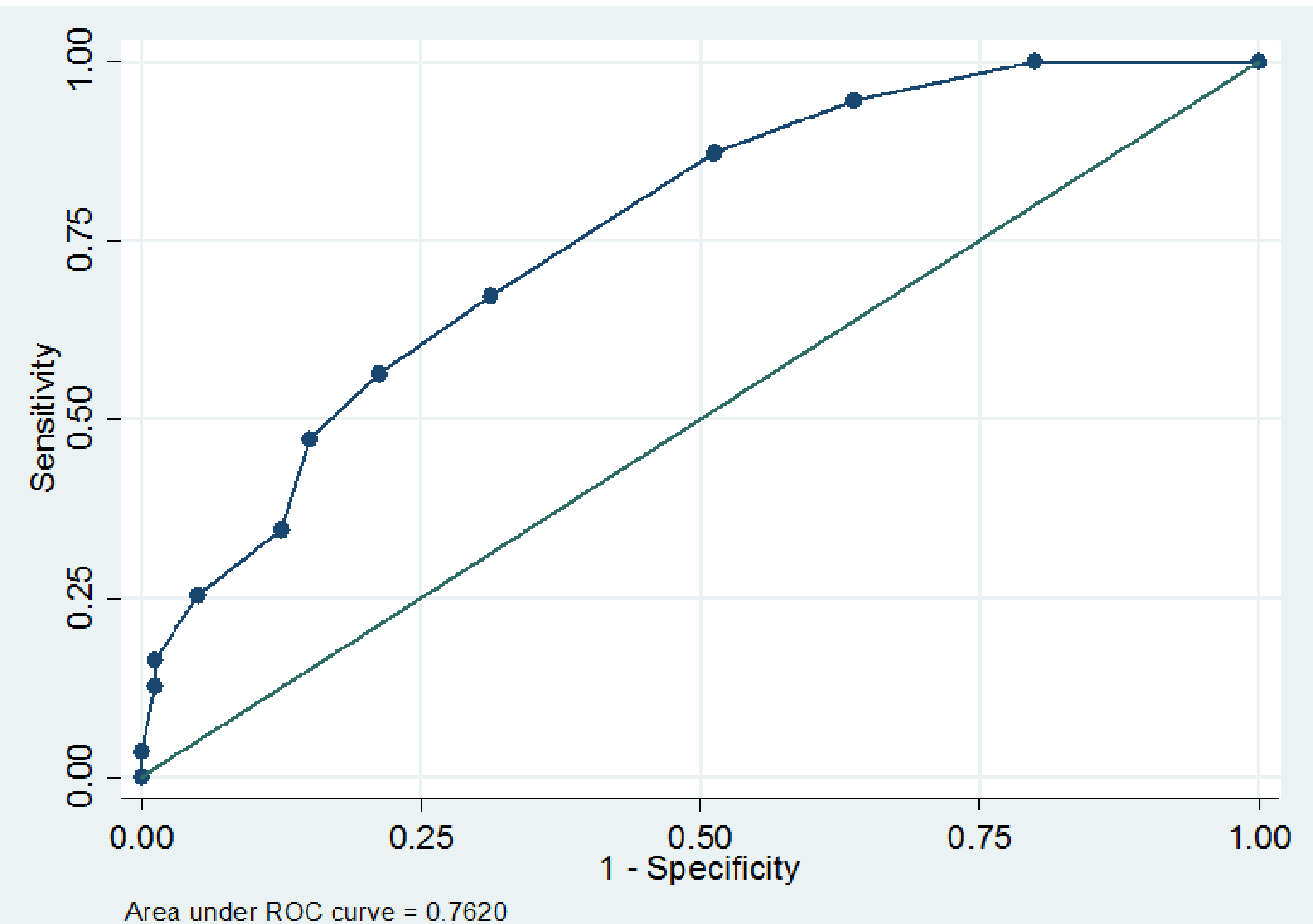

Gambar 2. Grafik AuROC MSOFA 24 Jam 


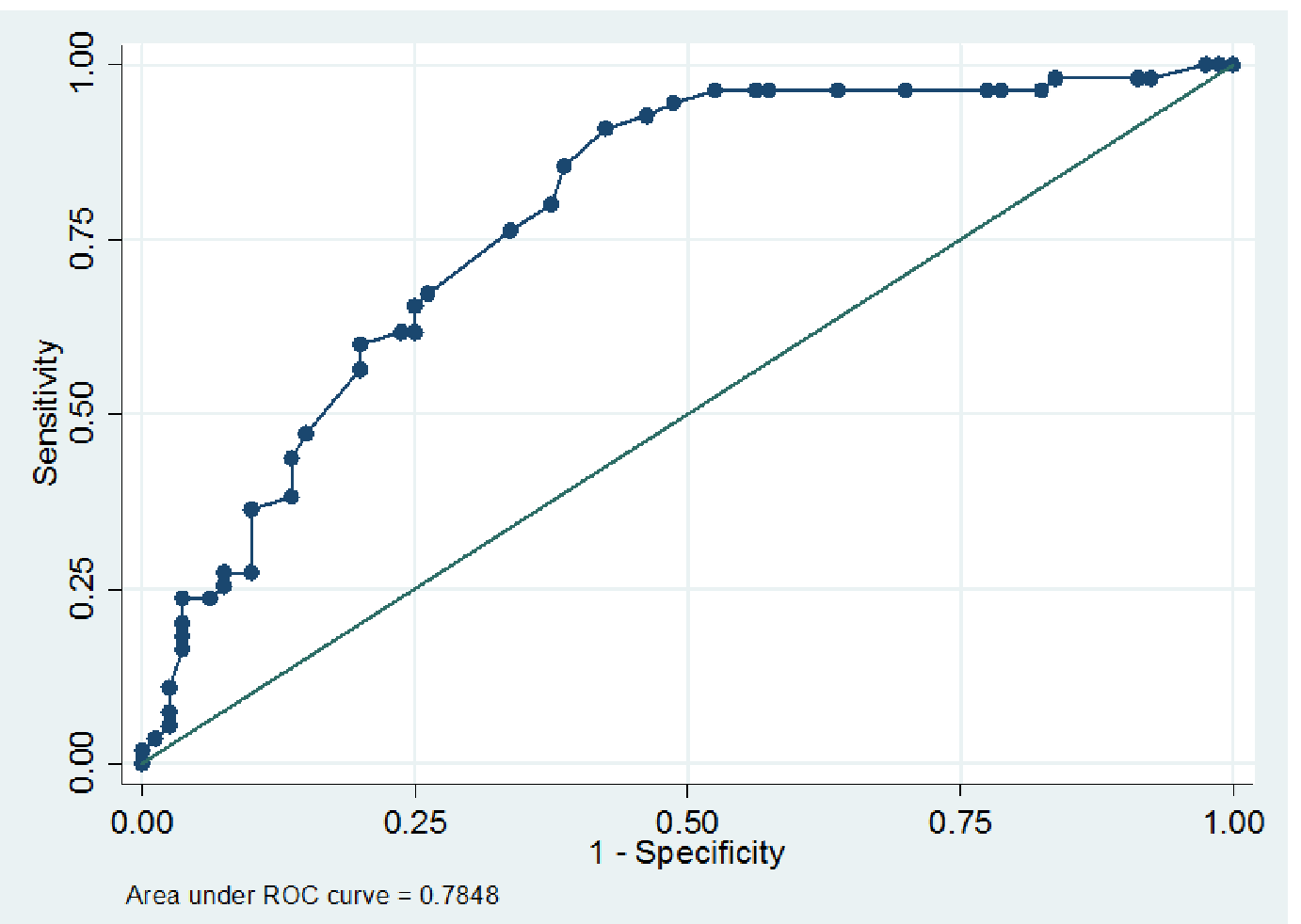

Gambar 5.3 Grafik AuROC SAPS 3 


\section{DAFTAR PUSTAKA}

1.Kim H,Lee H, Shon YJ, Paik H, Park HP. Validation of the APACHE IV model and its comparison with the APACHE II, SAPS 3, and Korean SAPS 3 models for the prediction of hospital mortality in a Korean surgical intensive care unit.Korean J Anesthesiol 2014; August 67(2): 115-122. DOI : $10.4097 /$ kjae.2014.67.2.115

2.Antonelli M, Moreno R, Vincent JL, Sprung CL, Mendoca A, Passarielo M. et al. Application of SOFA score to trauma patients. Intensive Care Med 1999; 25: 389-394

3.Fery-Lemonier E, Landais P, Loirat P, Kleinknecht D, Brivet F. Evaluation of severity scoring systems in ICUs : translation, conversion and definition ambiguities as a source of interobserver variability in Apache II, SAPS and OSF. Intensive Care Med 1995; 21:356-360

4.Taofik S, Senapathi TGA, Wiryana M. Perbandingan validitas sistem skoring APACHE-II, SOFA dan cSOFA (Customized Sequential Organ Failure Asessment) untuk memperkirakan mortalitas pasien non bedah yang dirawat di ruang perawatan intensif RSUP Sanglah. JAI 2015; 3: 45-49

5.Halim, D.A., Murni, T.W., Ike, S.R. Comparison of APACHE II, SOFA, and modified SOFA scores in predicting mortality of surgical patients in intensive care unit at Dr. Hasan Sadikin general hospital. Crit Care \& Shock 2009; 12:157-169.

6.Sedlon P, Kamenik L, Skvaril J, Maly M, Taborsky M, Zavoral M. Comparison of the accuracy and correctness of mortality estimates for Intensive Care Unit patients in the internal clinics of the Czech
Republic using APACHE II, APACHE IV, SAPS 3 and MPMoIII models. Med Glas 2016; 13(2):82-89

7.Qiao Q, Lu G, Li M, Shen Y, Xu D. Prediction of outcome in critically ill elderly patients using APACHE II and SOFA scores. The Journal of International Medical Research 2012; 40:1114-1121

8.The National Committee on NAICU. The National Audit on Adult Intensive Care Units (NAICU) : Report of 12 month Audit From $1^{\text {st }}$ July 2002 to $30^{\text {th }}$ June 2003. Malaysia: Ministry of Health Malaysia, November 2003.

9.Kwizera A, Dunser M, Nakibuuka J. National intensive care unit bed capacity and ICU patient characteristics in a low income country. BMC Research Notes2012, 5:475

10.Naved S, Siddiqui S, Khan F. APACHEII Score Correlation With Mortality And Length Of Stay In An Intensive Care Unit. Journal of the College of Physicians and Surgeons Pakistan. 2011; 21(1) :4-8. 